\title{
$1.000 \mathrm{kV}, 500 \mathrm{kV}$ 用ガス䎦縁タンク形避雷器の夏季の 日射量とタンク温度と漏れ電流に関する考察
}

$\begin{array}{ccc}\text { 正員 } & \text { 山形 芳文 } & \text { (東京電力) } \\ \text { 正員 } & \text { 下田 喜宏 } & \text { (東京電力) } \\ \text { 正員 } & \text { 近藤 真一 } & \text { (日立) } \\ \text { 正員 } & \text { 綿引 聡史 } & \text { (日立) } \\ \text { 正員 } & \text { 白川 晋吾 } & \text { (日立) }\end{array}$

Solar Radiation in Summer, Tank Surface Temperature and Leakage Current of $\mathrm{SF}_{6}$ Gas Insulated Type Surge Arresters for the $500 \mathrm{kV}, 1,000 \mathrm{kV}$ power systems

Yoshibumi Yamagata, Member (Tokyo Electric Power Co.)

Nobuhiro Shimoda, Member (Tokyo Electric Power Co.)

Kondo Shinichi, Member (Hitachi Ltd.)

Satoshi Watahiki, Member (Hitachi Ltd.)

Shingo Shirakawa, Member (Hitachi Ltd.)

There is a few data of temperature characteristics of $\mathrm{SF}_{6}$ gas tank type surge arresters. This paper describes the relation of solar radiation in summer, tank surface temperature and leakage current of $\mathrm{SF}_{6}$ gas insulated type surge arresters for the $1,000 \mathrm{kV}, 500 \mathrm{kV}$ power systems. The temperature of internal zinc oxide elements are evaluated as about $40^{\circ} \mathrm{C}_{\text {。 }}$

キーワード : 避雷器, 酸化亜鈶素子, 日射量, 温度

\section{1. まえがき}

電力需要に対応する高電圧大容量化送電の技術開発の一 貫として, $1,000 \mathrm{kV}$ 送変電機器の実用化検討が推進されて いる(1)。この中でも系統の建設コストや信頼性を決める重 要な要因として, 雷インパルス耐電圧值を設定することは 系統絶縁設計の根幹となるものであり，この值を決める避 雷器は重要な機器となる(2)。ガス絶縁タンク形避雷器の基 本性能を確認する際，日射による影製を把握しておくこと は避雷器内部の酸化亜鉛素子の課電寿命特性や安定性評価 を行うために重要な設計因子となる(3)(4)。すなわち, 避雷器 のタンク温度上昇による漏九電流への影響を把握すること は, ガス絶縁タンク形避雷器用酸化亜鉛素子の安定性評価 方法の妥当性の確認ができる。一方, 高性能酸化亜鉛素子 を用いた高エネルギー耐量の $1,000 \mathrm{kV}$ 用ガス絶縁タンク形 避雷器(5)(6)(7)は平成 8 年 2 月に我が国で初の課電を開始し, すでに約 1 年半以上の課電により実用性能の確認が実施さ れている。本論文では，日射量の高い夏季時(平成 9 年 8 月) に $1,000 \mathrm{kV}$ と $500 \mathrm{kV}$ 用ガス絶縁タンク形避雷器を用いて日 射量と避雷器のタンク温度と漏れ電流の関係を求めたの で,これらについて述へる。

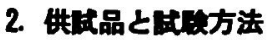

\section{1 栱品}

ここで供試した $1,000 \mathrm{kV}$ と $500 \mathrm{kV}$ 用ガス絶縁タンク形避 雷器の仕様は表 1 に示す。これらはいずれも酸化亜鉛素子 (ZnO 素子)をタンク内に内蔵した高性能酸化亜鉛形避雷器 (8)(9)(10)(11)である。図 1 にはこれらガス絶縁タンク形避雷器 の外観を示す。

表 $11,000 \mathrm{kV}, 500 \mathrm{kV}$ ガス絶縁タンク形避雷器の特性

Table. 1 Charateristics of $1,000 \mathrm{kV}, 500 \mathrm{kV}$ Tank Type Surge Arresters

\begin{tabular}{|c|c|c|}
\hline 項目 & $1,000 \mathrm{kV}$ & $500 \mathrm{kV}$ \\
\hline 系統最高電压 & $1,100 \mathrm{kV} / \sqrt{3}$ & $550 \mathrm{kV} / \sqrt{3}$ \\
\hline 制限電压 & & \\
$/ 10 \mathrm{kA}$ & $1,550 \mathrm{kV}$ & $870 \mathrm{kV}$ \\
$/ 20 \mathrm{kA}$ & $1,620 \mathrm{kV}$ & $940 \mathrm{kV}$ \\
\hline 短時間過電厌 & $55 \mathrm{MJ}$ & $3.3 \mathrm{MJ}$ \\
(TOV)酎量 & & \\
\hline
\end{tabular}

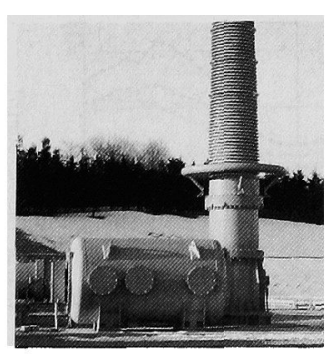

(a) $1,000 \mathrm{kV}$ 用

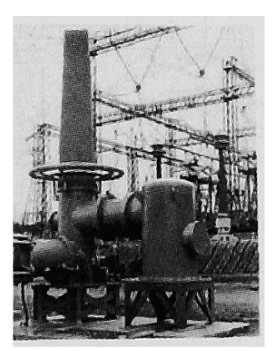

(b) $500 \mathrm{kV}$ 用
図 $11,000 \mathrm{kV}, 500 \mathrm{kV}$ 用ガス絶緑タンク形避雷器の外観 Fig.1 Outside View of 1,000kV, 500kV Tank Type Surge Arresters 


\section{2 时貼方法}

避雷器に所定の電圧を印加した状態で，時間的推移のもと に日射量と周团温度（気温）に対するタンク温度と漏れ電流 の関係を計測する。

(1)日射量の測定方法 : 日射量は避雷器の設置されている數地 内に日射量計（全天日射計）を設置し，測定する。周囲温度 は百葉箱内に設置の温度計にて测定する。

(2)タンク温度の測定方法 : 避雷器のタンク温度は $1,000 \mathrm{kV}$ 用 避雷器および $500 \mathrm{kV}$ 用避雷器各々に関し, 熱電対を用いて温 度記録計により測定を行う。

(3)印加電王, 避雷器漏九笔流の測定方法: 印加電圧は $1,000 \mathrm{kV} ， 500 \mathrm{kV}$ いずれむ光PD(変成器)を用いて測定する。

避雷器の漏れ電流は図 2 に示すような回路で，日射量，周 因温度, 印加電圧に対する全漏れ電流，抵抗分電流の変化を 測定する。

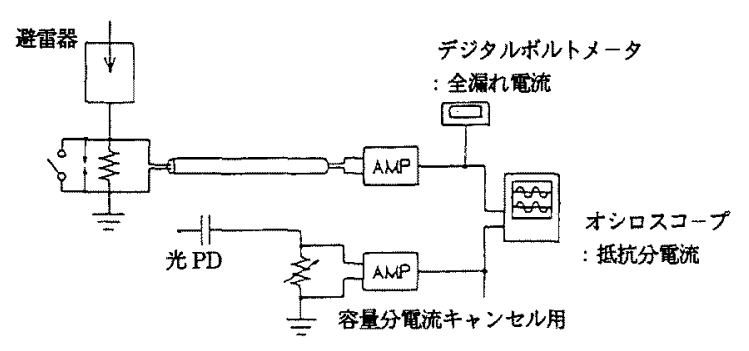

図 2 避雷器の漏九電流測定回路 Fig. 2 Test Circuit of Measurement of Leakage Current of $1,000 \mathrm{kV}$ and $500 \mathrm{kV}$ Surge Arresters

\section{3. 実睌結果}

ここでは実系統に接続された $1,000 \mathrm{kV}$ と $500 \mathrm{kV}$ 用ガス絶縁 タンク形避雷器について，日射量とタンク温度, 気温（周囲 埧度）の関係，印加電圧一避雷器漏九電流（全漏九電流，抵 抗分電流）上タンク温度，気温（周国温度）との関係を上記 の方法で測定した。

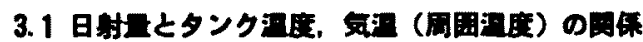

园 3 は $1,000 \mathrm{kV}$ 用避雷器の日射量とタンク温度の関係を示

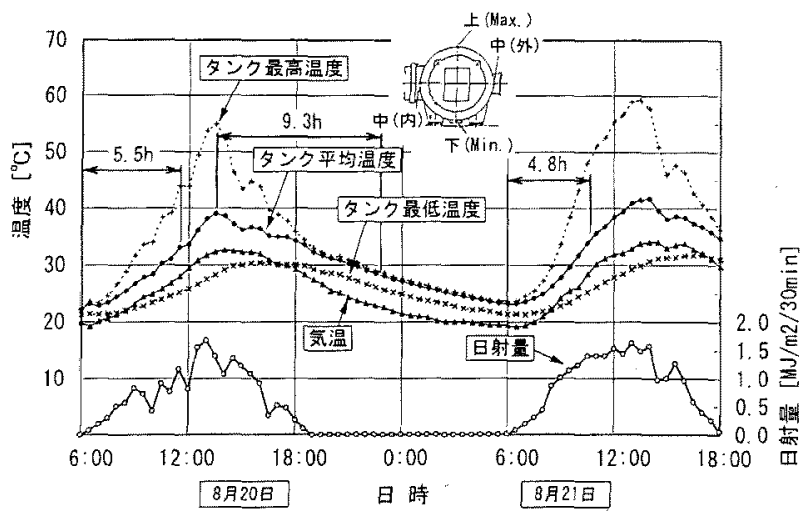

図 31,000kV 用タンク形避雷器の日射量とタンク盜度との関係 Fig. 3 The Relation of Solar Radiation in Summer, Tank Surface Temperature of $1,000 \mathrm{kV}$ Tank Type Surge Arrester
す。タンク温度は测定テータから測定点での平均温度が得ら れ，最高温度，最低温度を含めてこれらを図中に示す。図4 には図 3 と同様に, $500 \mathrm{kV}$ 用避雷器の日射量とタンク温度の関 係を示す。

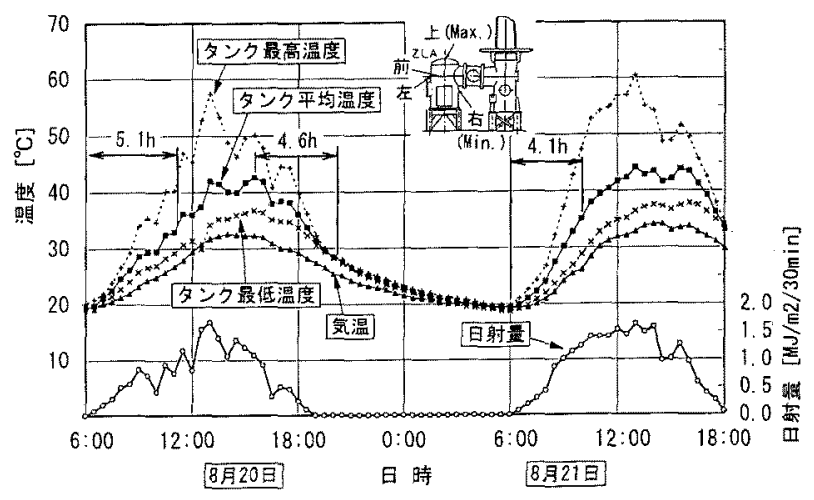

図 $4500 \mathrm{kV}$ 用タンク形避雷器の日射量とタンク温度之の関係 Fig.4 The Relation of Solar Radiation in Summer, Tank Surface Temperature of $500 \mathrm{kV}$ Tank Type Surge Arrester

放熱時定数は図中に示すように，1,000kV 用避雷器では 約 $9.3 \mathrm{~h}$ であり， $500 \mathrm{kV}$ 用避雷器の $4.6 \mathrm{~h}$ に比較して大きい ことが分る。これは避雷器タンクの容積比が $500 \mathrm{kV}$ に対 し，6.2 倍と大きいことに起因している。なお，500kV 用 避雷器では気温の最低值とタンク平均温度が一致してお り, $500 \mathrm{kV}$ 用避雷器は外気温と同様な温度推移を示すこと が分かる。1,000kV 用避雷器では一日の外気温の低下まで タンク温度は低下していかないとを示している。

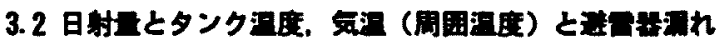

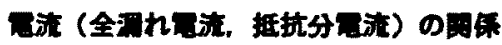

夏季時における試験として，印加電圧上漏れ電流（全漏 れ電流，抵抗分電流）の関係を求めた。図 5 はこの例とし て $1,000 \mathrm{kV}$ 用避雷器の漏れ電流波形（全漏れ電流，抵抗分 電流）を示す。これらによって求めた測定值に気温とタン ク平均温度を併記して, 図 6 は $1,000 \mathrm{kV}$ 用, 図 7 は $500 \mathrm{kV}$ 用避雷器の印加電圧，漏九電流，タンク温度，気温の関係 を示す。漏九電流（全漏九電流，抵抗分電流）については 印加電圧により変動することから，電圧補正した值と測定

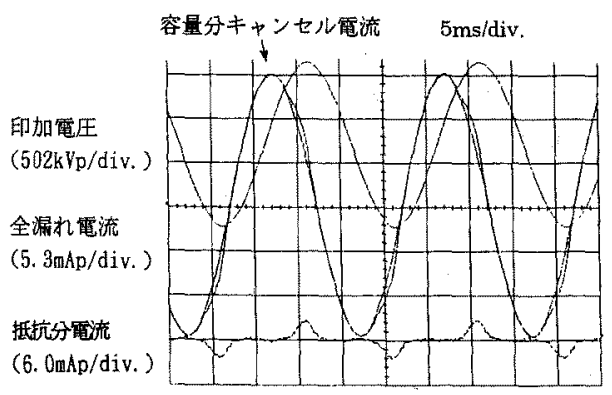

图 $51,000 \mathrm{kV}$ 用避雷器の漏九電流波形 (全漏九電流, 抵抗分電流) Fig.5 Total and Resistive Leakage Current Wave Forms of $1,000 \mathrm{kV}$ Tank Type Surge Arrester 
した漏れ電流を併記している。

(1) $1,000 \mathrm{kV}$ 用避雷器: 全漏れ電流が $10.7 \mathrm{~mA} \rightarrow 11.25 \mathrm{~mA}$ と $5.1 \%$ 增加し, 抵抗分電流は $2.41 \mathrm{~mA} \rightarrow 2.69 \mathrm{~mA}$ 之 $11.6 \%$ 増加 している。気温と $1,000 \mathrm{kV}$ 避雷器のタンク温度では最高温 度の差 $6.4^{\circ} \mathrm{C}(=39-32.6)$ が生じている。
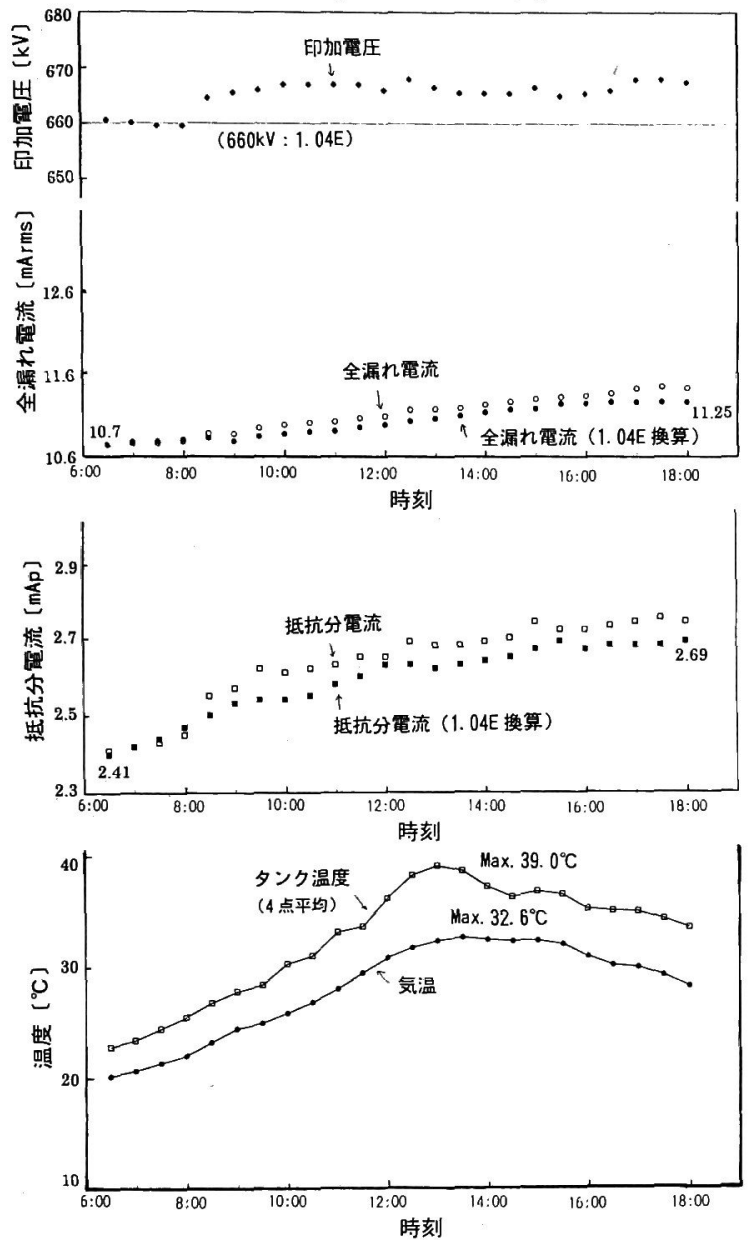

図 6 $1,000 \mathrm{kV}$ 用避雷器のタンク温度之漏れ電流の関係 Fig.6 The Relation of Tank Surface Temperature and Leakage Current of 1,000kV Tank Type Surge Arresters

(2) $500 \mathrm{kV}$ 用避雷器: 全漏れ電流が $2.36 \mathrm{~mA} \rightarrow 2.51 \mathrm{~mA}$ と $6.4 \%$ 増加し，抵抗分電流は $0.34 \mathrm{~mA} \rightarrow 0.399 \mathrm{~mA}$ と $17.4 \%$ 増 加している。気温と $1,000 \mathrm{kV}$ 避雷器のタンク温度では最高 温度の差 $8.5^{\circ} \mathrm{C}(=42.6-34.1)$ が生じている。

$1,000 \mathrm{kV} ， 500 \mathrm{kV}$ 用避雷器いずれにおいても日射により 避雷器タンクが温度上昇し, この熱伝達の影響により, 避 雷器漏れ電流 (全漏れ電流, 抵抗分電流) は時間遅れで増 加していることが分かる。

\section{3 タンク酒度上严と $\mathrm{ZnO}$ 秦于目度の间保}

当該 $1,000 \mathrm{kV}$ 避雷器は大型の㻴境試験室に搬入し(7), 冷熱試 験時のタンク温度や内部 $2 \mathrm{n} 0$ 素子の温度推移を測定してい る。図 8 にこれらの測定データの一部を示す。恒温室の周囲 温度の上昇に伴い, タンク温度は上昇し, これに対応して Zn0 素子温度も追随して上昇することが分かる。
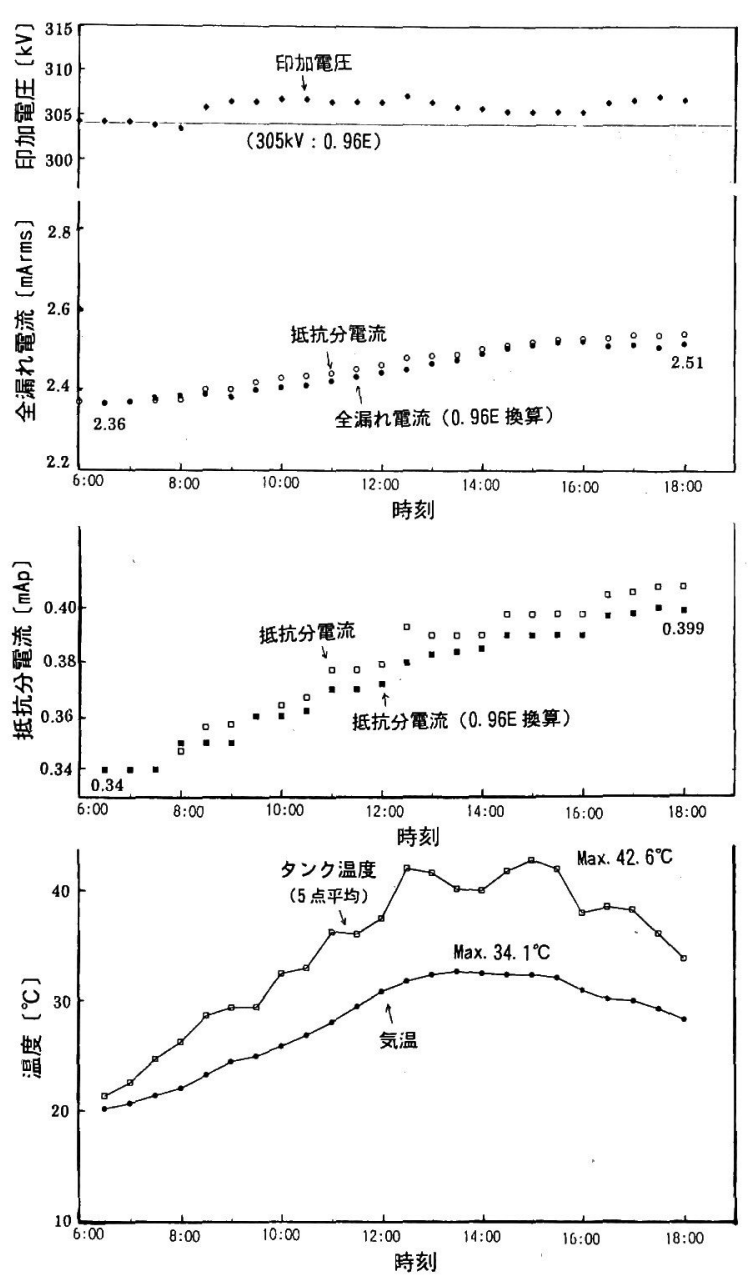

図 $7500 \mathrm{kV}$ 用避雷器のタンク温度と漏れ電流の関係 Fig.7 The Relation of Tank Surface Temperature and Leakgge Current of 500kV Tank Type Surge Arresters

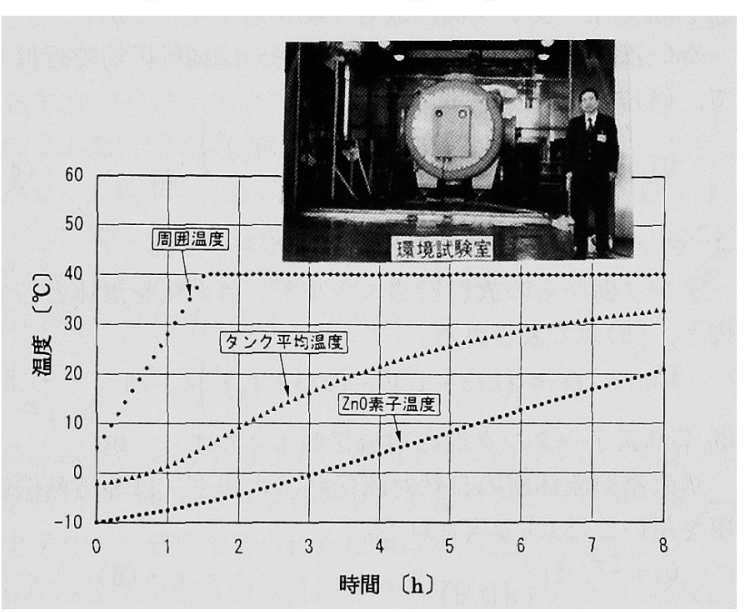

図 $81,000 \mathrm{kV}$ 用タンク形避雷器の冷熱試験時における タンク温度と $\mathrm{ZnO}$ 素子温度の関係

Fig.8 The Relation between Tank Surface Temperature and $\mathrm{ZnO}$ Elements Temperature of $1,000 \mathrm{kV}$ Tank Type Surge Arresters in Heat Cycle Test 


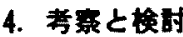

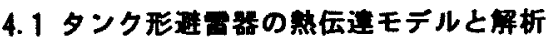

前述のように日射量とタンク温度と漏れ電流の変化を実器 によって求めたので，ここではタンク形避雷器の熱伝導モデ ルを考えて, 避雷器内部の酸化亚鉛素子の温度上昇について 考察する。

タンク形避雷器はタンクの中心部に酸化亚鈶素子を配固し ていることから，避雷器の熱伝導モデルは図 9 のように示さ れる。なおこのモデルでは軸方向への伝導伝熱は無視して いる。
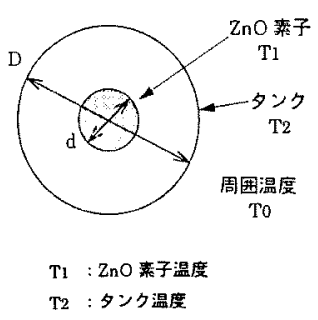

To : 周围温度 (気盢)

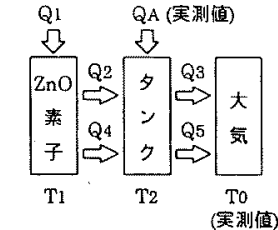

QA : 日射エネルギー

Q1：ZnO菜子の発努エネルギー

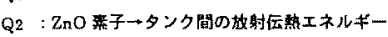

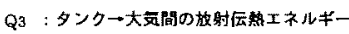

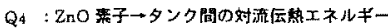

Q5 : タンクー大気間の对流层槊エネルキー
図 9 タンク形避雷器の熱伝導モデル

Fig.9 Thermal Equivalence Model of Tank Type Surge Arresters

(1) 日射量: A

太陽の直射は外気温度に対応し，日の出から日没までは 正弦波状に変化し，日没後は直射なしと近似すると(1)式で 表わされる。太陽の直射エネルギーは(2)式で示される(12)。
$A(t)=A_{0} \sin (2 \pi t / 24)$
...(1)
$Q A(t)=S \cdot A(t)$
. * (2)

(2) $2 \mathrm{n} 0$ 素子の発熱 : Q1

Zn0素子の発熱は(3)式で表される。

$$
\mathrm{Q}_{1}=\mathrm{k} \cdot \mathrm{V} \cdot \mathrm{Ir} \cdot \mathrm{t} \quad \cdot \cdot \cdot(3)
$$

(3) Zn0素子 $\rightarrow$ タク間の放射伝熱工ネルギー:Q2

Zn0 素子からの放射伝熱エネルギーは同軸円筒で近似し

て，(4)式で表される。

$$
Q 2=\frac{\pi \cdot d \cdot \sigma\left\{\left(273+T_{1}\right)^{4}-\left(273+T_{2}\right)^{4}\right\}}{1 / \varepsilon_{1}+d / D\left(1 / \varepsilon_{2}-1\right)} \cdot \Delta t \quad \cdot \cdot(4)
$$

(4) タンク $\rightarrow$ 大気間の放射伝熱エネルギー: Q3

タンク面からの放射伝熱エネルギーは大気を黒体として 考え，(5)式で表される。

$$
\mathrm{Q}_{3}=\pi \cdot \mathrm{D} \cdot \sigma\left\{\left(273+\mathrm{T}_{1}\right)^{4}-\left(273+\mathrm{T}_{0}\right)^{4}\right\} \mathrm{E}_{3} \cdot \Delta \mathrm{t} \cdot \text { ・ (5) }
$$

(5) Zn0秦子ータンク間の対流伝熱エネルギー：Q4

垂直密閉流体層の自然対流伝熱エネルギーは等価熱伝達 率を用いて $(6)$ 式で表される。

$$
Q_{4}=2 \pi \cdot \alpha_{1} / \ln (\mathrm{D} / \mathrm{d}) \cdot \Delta \mathrm{t}
$$

(6) タンクー大気間の対流伝熱エネルギー：Q5

垂直円筒侧面からのみの対流伝熱量は(7)式で表される。

$$
Q_{5}=\alpha_{2} \cdot \pi \cdot \mathrm{D}\left(\mathrm{T}_{2}-\mathrm{T}_{0}\right) \cdot \Delta \mathfrak{t}
$$$$
\cdot \cdot(7)
$$

ここで， $A_{0}:$ 日射量の最大值 $\left[\mathrm{J} / \mathrm{m}^{2}\right], S$ : 等洒直射受面積 $\left[\mathrm{m}^{2}\right]$, $\mathrm{k}$ : 係数, $\mathrm{V}$ :印加電圧波高值 $(\mathrm{kV}), \mathrm{Ir}$ : 抵抗分電流 $(\mathrm{mA}), \mathrm{Cp} 1$ : Zn0 素子の比熱 $\left[\mathrm{J} / \mathrm{g} \cdot{ }^{\circ} \mathrm{C}\right], \mathrm{Cp} 2:$ タンクの比熱 $\left[\mathrm{J} / \mathrm{g} \cdot{ }^{\circ} \mathrm{C}\right]$, $M_{1}:$ Zn0 素子の質量 $[\mathrm{kg}], M_{2}$ : タンクの質量 $[\mathrm{kg}] ， \sigma:$ ステ ファン・ボルツマン定数, $\mathrm{d}: \mathrm{Zn} 0$ 素子モテル径 $[\mathrm{m}], \mathrm{D}:$ タ

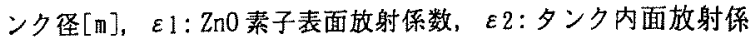
数, $\varepsilon 3:$ タンク外面放射係数， $\alpha 1: Z \mathrm{n} 0$ 素子ータンク間の 対流熱伝達率, $\alpha_{2}:$ タンク $\rightarrow$ 大気間の対流熱伝達率, $\Delta \mathrm{t}$ : 単位時間を示す。

$\mathrm{Zn} 0$ 素子の温度変化 $\Delta \mathrm{T}_{1}$ とタンク温度の変化 $\Delta \mathrm{T}_{2}$ は下記 の計算式(7)，(8)式により求められる。

$$
\begin{aligned}
& \Delta \mathrm{T}_{1}=\left(\mathrm{Q}_{1}-\mathrm{Q}_{2}-\mathrm{Q}_{4}\right) /\left(\mathrm{C}_{\mathrm{p} 1} \times \mathrm{M}_{1}\right) \\
& \Delta \mathrm{T}_{2}=\left(\mathrm{Q}_{2}-\mathrm{Q}_{3}+\mathrm{Q}_{4}-\mathrm{Q}_{5}\right) /\left(\mathrm{C}_{\mathrm{p} 2} \times \mathrm{M}_{2}\right) \cdots(8) \\
& \Delta \cdot(9)
\end{aligned}
$$

これらの結果を図 $10 k 1,000 \mathrm{kV}$ 用，図 11 に $500 \mathrm{kV}$ 用夕 ンク形避雷器の日射量とタンク温度, $2 \mathrm{n} 0$ 素子温度の解析 結果を示す。Zn0 素子温度は気温に対して約 $10 \%$ 上昇してい る。なお，図中の日射量と気温は実測值を表示している。 日射量がない場合の $1,000 \mathrm{kV}$ 用, $500 \mathrm{kV}$ 用タンク形避雷器の タンク温度，Zn0 素子温度の関係は図 12, 図 13 に示す。

次に, 図 14 には $1,000 \mathrm{kV}$ 用避雷器が短時問過電圧 (TOV) 責務の注人エネルギー $300 \mathrm{~J} / \mathrm{cm}^{3}$ 相当を吸収した時の温度特性 のシミュレーション結果を示す。エネルギー吸収後, 過渡的 に温度上昇するが，元の温度に復帰していく状況が分かる。

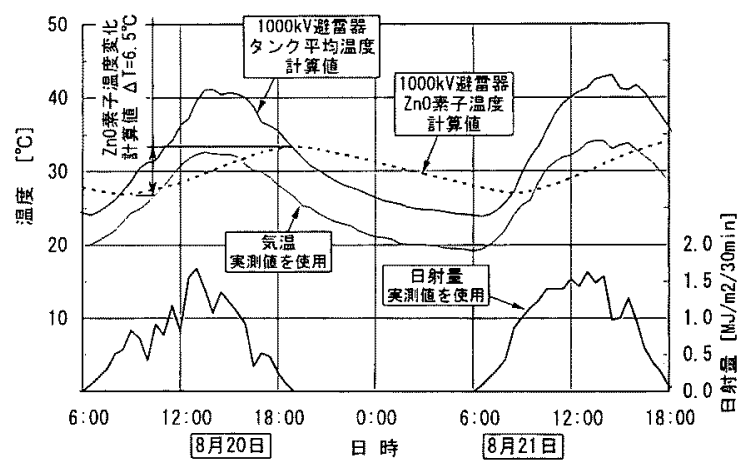

図 $101,000 \mathrm{kV}$ 用タンク形避雷器の日射量とタンク温度と $\mathrm{ZnO}$ 素子温度の関係 (日射量あり)

Fig.10 The Relation of Tank Surface Temperature and $\mathrm{ZnO}$ Elements of $1,000 \mathrm{kV}$ Tank Type Surge Arrester with Solar Radiation in Summer

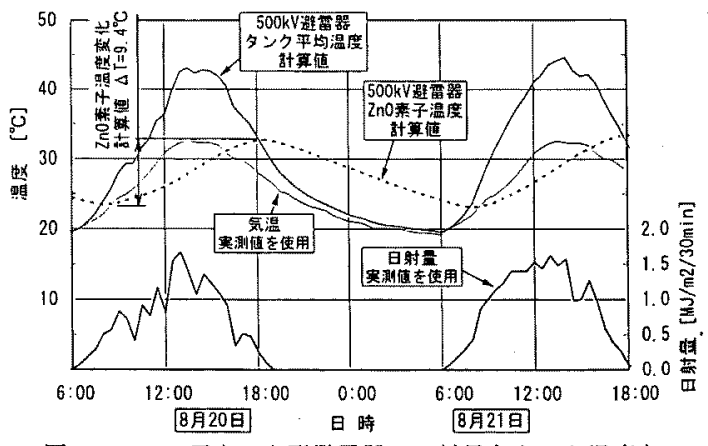

図 $11500 \mathrm{kV}$ 用タンク形避雷器の日射量とタンク温度と $\mathrm{ZnO}$ 素子温度の閔係 (日射量あり)

Fig.11 The Relation of Tank Surface Temperature and $\mathrm{ZnO}$ Elements of $500 \mathrm{kV}$ Tank Type Surge Arrester with Solar Radiation in Summer 


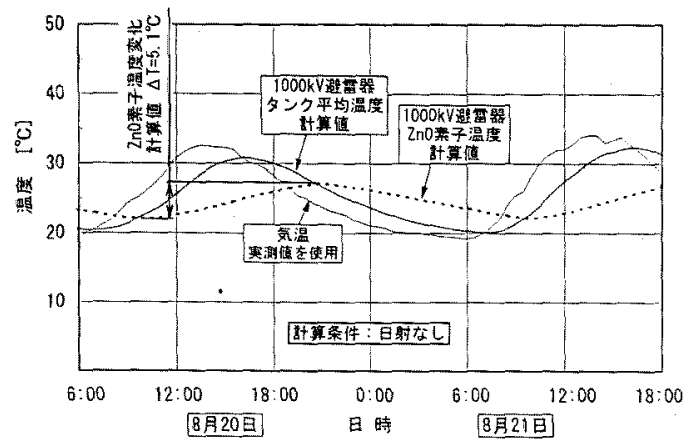

図 $121,000 \mathrm{kV}$ 用タンタ形避雷器のタンク温度と $\mathrm{ZnO}$ 素子温度の 関保（日射量なし）

Fig.12 The Relation of Tank Surface Temperature and $\mathrm{ZnO}$ Elements of 1,000kV Tank Type Surge Arrester without Solar Radiation in Summer

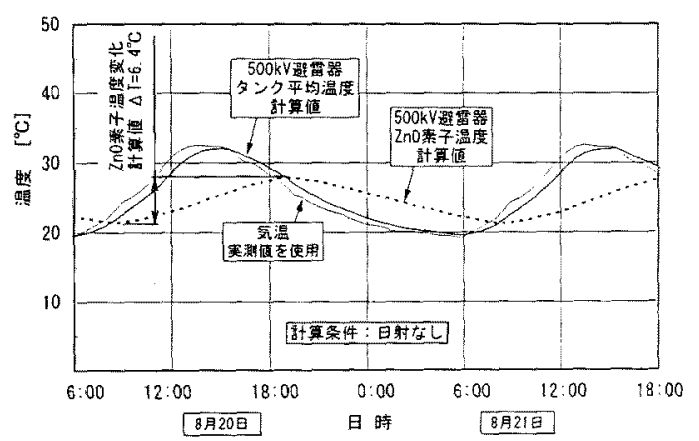

図 $13500 \mathrm{kV}$ 用タンク形避雷器のタンク温度と $\mathrm{ZnO}$ 素子 混度の関係（日射量なし）

Fig 13 The Relation of Tank Surface Temperature and $\mathrm{ZnO}$ Elements of $500 \mathrm{kV}$ Tank Type Surge Arrester without Solar Radiation in Summer

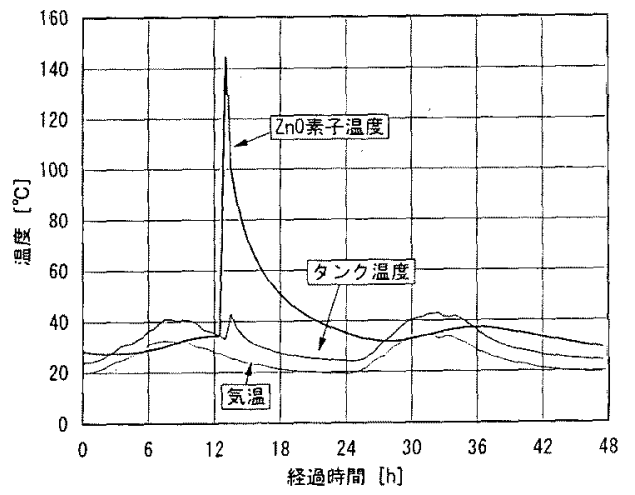

図 $141,000 \mathrm{kV}$ 用タンク形避雷器の TOV $\left(300 \mathrm{~J} / \mathrm{cm}^{3}\right.$ 相当) 吸収時の温度計算

Fig.14 Temperature Transition Characteristics of 1,000kV Tank Type Surge Arrester in case of TOV Energy Absorption

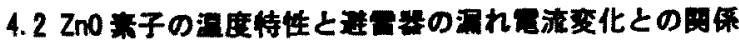

$\mathrm{Zn} 0$ 素子は素子固有の温度特性を有しており, 温度によ り漏机電流が変化する特性を有している(3)。これらの温度 特性から前述の実測の漏机電流変化とを対比することで，

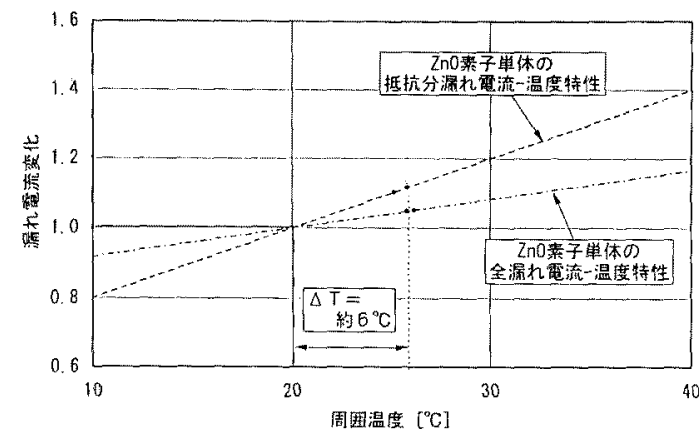

困 $151,000 \mathrm{kV}$ 用タンク形避雷器の漏孔電流変化と周国 温度との関係

Fig. 15 The Relation between Change of Leakage Current and the ambient Temperature of $1,000 \mathrm{kV}$ Type Surge Arresters

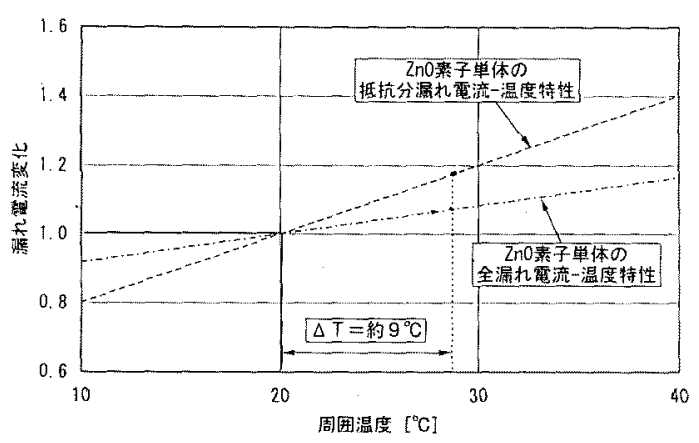

図16500kV用タンク形避雷器の漏れ電流変化之周囲 温度との関係

Fig. 16 The Relation between Change of Leakage Current and the ambient Temperature of $500 \mathrm{kV}$ Type Surge Arresters

ここではタンク形避雷器内部の $\mathrm{ZnO}$ 素子の温度変化を推定す る。図 15 と図 16 は $1,000 \mathrm{kV}$ と $500 \mathrm{kV}$ タンク形避雷器の気 温(周囲温度)と漏机電流変化の関係を示す。このグラフの 破線部は ZnO 素子单体の温度特性を示しており，こ㣗に日 射による漏れ電流変化をプロットして Zn0 素子温度変化を 求める。 $1,000 \mathrm{kV}$ 用避雷器では約 $6^{\circ} \mathrm{C}, 500 \mathrm{kV}$ 用避雷器では 約 $9^{\circ} \mathrm{Cが}$ 得られる。日射によりタンク温度が上舁し：この 熱伝達によりタンク内部の 2no 素子に温度変化が生じ, 避 雷器の漏れ電流が変化することが分かる。

\section{5.まとめ}

実系統に接続の $1,000 \mathrm{kV}$ 上 $00 \mathrm{kV}$ ガス絶縁タシク形避雷 器を用いて，夏季の日射量とタンク温度と㵐れ電流の関係 を求めた。本研究で得られた成果は次の通りである。

(1) $1000 \mathrm{kV}$ 用避雷器は夏期時の $660 \mathrm{kV}$ (1.04E 相当) 運転, 気温 Hax. $32.6^{\circ} \mathrm{C}$, タンク平均温度 Max. $39^{\circ} \mathrm{C}$ の上昇に対し, 全漏孔電流は的 $5 \%$ ，抵抗分漏九電流は約 11 程度变化する が，健全に稼動している。Zn0 素子の温度特性と $1,000 \mathrm{kV}$ 用避雷器の漏れ電流変化とを対比させることにより，Zn0 素 
子の温度変化 $6^{\circ} \mathrm{C}$ が得られた。

(2) $500 \mathrm{kV}$ 用避雷器は夏期時の $305 \mathrm{kV}(0.96 \mathrm{E}$ 相当) 運転,

気温 Max. $34.1^{\circ} \mathrm{C}$, タンク平均温度 Max. $42.6^{\circ} \mathrm{C}$ の上昇に対 し, 全漏九電流は約 $8 \%$, 抵抗分漏九電流は約 $17 \%$ 程度変化 するが，健全に稼動している。2n0 素子の温度特性と $500 \mathrm{kV}$ 用避雷器の漏九電流変化とを対比させることにより， $\mathrm{n} 0$ 素子の温度変化 $9^{\circ} \mathrm{Cが}$ 得られた。

（平成 9 年 12 月 18 日受付，同 10 年 3 月 18 日再受付)

\section{文就}

(1)山形:「100万 V 変電機器開発はここまで進んだ」, 電学 論 B， 115 巻 11 号，平成 7 年(1995)

(2)上田,山形,小島,白川,今滝:「酸化亜鉛形避雷器」,電気評論, 第 200 号, 1983

(3)酸化亜鉛形避雷器の特性評価調査専門委員会:「酸化亜鉛 避雷器の特性と評価試験法」, 電学技術報告第 474 号, 1993

(4)白川:「酸化覀鉛形避雷器の最近の動向」, 電学論 B, 114 巻 5 号, 平成 6 年(1994)

(5)中田, 山田, 大石, 白川: $\lceil 1,000 \mathrm{kV}$ 用避雷器の短時間過電 圧耐量について」, 電学論 B,115 巻 11 号, 平成 7 年, (1995)

(6) Y. Nakada, S. Yamada, K. Oishi, S. Shirakawa : “ Temporary Overvol tage Capability of Surge Arresters for $1000 \mathrm{kV}$ Power Systems" , Electrical Engineering in Japan, Vol. 117, No. 3, 1996, Scripta Technica, Inc.

(7)山形, 田中, 白川, 飯村, 山田, 小沢：「 $1,000 \mathrm{kV}$ 用避雷器 の開発-高エネルギ-耐量素子避雷器一」, 日立評論, Vol. 76, No.12 (1994-12)

(8) 山形,菅,白川,宇治田:「酸化亜鉛形避雷器の高性能化」, 電 学高電圧研資, No.HV-91-24,1991

(9)白川,菅,宇治田:「酸化亜鉛形避雷器適用に関する最近の諸 問題一酸化覀鉛形避雷器の高性能化一」, 電学開閉保護研 資, No.SP-92-2, 1992

(10)白川: 「避雷器の開発状況之異常電圧抑制効果」, 電気評論, 第 320 号, 1992

(11)白川,山田:「酸化亜鉛形避雷器の高性能化亡実用化」, 電機, 第 592 号, 1997

(12)水越,小沢,白川,中野,饭村:「タンク形避雷器の熱安定性」， 電学開開保護研資, No.SPD-84-26, 1984

(13)避雷器標準委員会:「酸化亜鉛形避雷器」, JEC-217-1984, 電気学会電気規格調查会標準規格, 1984
山形 苊文（正員） 1953 年 11 月 3 日生。1976 年 3 月横浜国 立大学工学部電気工学科卒業。1978 年 3 月横浜国 立大学大学院工学研究科電気工学専攻修了。東京電 力入社。主として, 変電機器の技術開発・保守業務 に従事。現在, 送変電建設本部 100 万 V 変電技術 担当副部長。

下田 뎐 （正員） 1967 年 3 月 8 日生。1989 年 3 月慶応大 学理工学部電気工学科卒業。1991 年 3 月曼応大学 大学院理工学研究科電気工学専攻修了。東京電力 入社。主として，変電機器の技術開発・建設技術に 従事。現在，送変電建設本部 100 万 V 変電技術グ ループ。

近蕃 一（正員）1974 年 12 月 24 日生。1993 年 3 月新潟県立

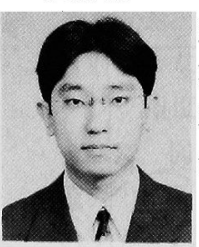
新潟工業高等学校電気科卒業。(株)日立製作所日立 研究所入所。1996 年 3 月日立茨城工業専門学院 卒業。現在，電力・電機開発本部に所属。主に避 雷器の研究開発業務に従事。

地引（正員） 1970 年 3 月 1 日生。1992 年 4 月茨城

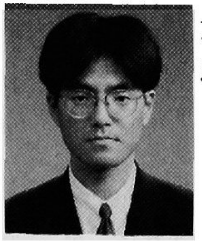
大学理学部物理学科卒業。(株)日立製作所入社。 以来，国分工場にて，主に避雷器の業務に従事。

白川 晋吾（正員） 1944 年 3 月 8 日生。1966 年 3 月山口

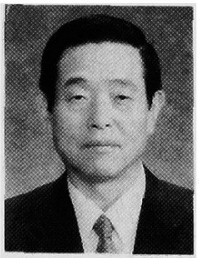
大学工学部電気工学科卒業。1968 年 3 月九州工 業大学大学院工学研究科電気工学尃攻修了。(株) 日立製作所入社。以来,国分工場にて,主に避雷器, セラミックス抵抗体式ガス絶縁N G Rの開発業務 に従事。工学博士 (九州大学)。現在，国分工場力゙ 又絶縁開閉装置部部長補佐主任技師。1988 年, 1994 年発明協会発明奨励賞, 1997 年JEMA進歩賞, 1997 年電気学会論文賞受賞。IEEE Senior Member 